\title{
The Environmental Crisis as a Good Case for an Intellectual and Practical Integration Between Philosophy and Science
}

\author{
Donato Bergandi (2013) The Structural Links Between Ecology, \\ Evolution, and Ethics: The Virtuous Epistemic Circle. Springer, \\ Dordrecht, ISBN: 978-94-007-5066-1, 179 pp, \$159.00 (Hardback)
}

\author{
Nei de Freitas Nunes-Neto ${ }^{1}$ \\ Published online: 3 June 2015 \\ (C) Springer Science+Business Media Dordrecht 2015
}

\section{Overview}

Donato Bergandi is a Professor of the Muséum National d'Histoire Naturelle in Paris and has produced important works in philosophy of ecology and environmental ethics, on central topics such as holism, reductionism and sustainable development. He organized this book taking as a starting point an international workshop that he coordinated in 2005. The workshop, entitled "Between the Philosophy of Biology and the Philosophy of Ecology: Evolutionisms, Ecologies and Ethics," had contributions from very prominent researchers, including Bergandi himself, which compose the eleven chapters of the book.

In what follows I will offer a brief examination of the eleven chapters. Although the chapters are independent from one another, in my review they are grouped according to some features they share (of course, this is only one way to group them, among many other, probably better, ways). In my comments, I'll also point to some associated possible research issues.

Moreover, although the book doesn't approach (at least not directly) educational issues, in my review I will point to such issues because there are quite interesting consequences for education from the historical and philosophical debates described in the book.

In the very beginning of the first chapter, entitled "Ecology, Evolution, Ethics: In Search of a Meta-paradigm - An Introduction," Bergandi develops a central thesis that pervades the whole book:

Over the last decades in particular, there has emerged a need for an interconnecting meta-paradigm that integrates more strictly evolutionary studies, biodiversity studies and the ethical frameworks that are most appropriate for allowing a lasting co-evolution between natural and social systems. Today such a need is more than a mere luxury, it is an epistemological and practical necessity. (p. 1)

This is a very nice quality of the book: the recognition that an integrated understanding of ecology, evolution and ethics is not a mere luxury, but an epistemological and practical

Nei de Freitas Nunes-Neto

neineto@ufba.br

1 Institute of Biology, Federal University of Bahia, Salvador, Brazil 
necessity. To point to this integration as a "practical necessity" is very welcome since he asks us to go beyond knowledge or understanding (epistemic virtues), reaching moral virtues instantiated in our social practices and institutions. In fact, we really need adequate practices and institutions that could implement what we already know about biological, ecological and social-ecological systems.

After presenting the general idea, Bergandi offers a brief presentation of the book chapters. Then, he moves to-as he calls it - an interweaved history of ecology, evolution and ethics, pointing to some landmarks. Here, Bergandi shows us the interconnections among the disciplines in a very didactical way. This is a positive feature for the use of this chapter by university professors, as well as pre-service or in-service high school biology teachers who want to contextualize historically and philosophically (here, mainly, in the ethical sense) the scientific contents in classes.

Particularly, Bergandi appeals to the idea of transactor as a central conceptual tool for the integration between ecology, evolution and ethics. This idea comes from Dewey (1930/ 1984) and Dewey and Bentley (1949/1989), as part of a distinction between "self-action," "inter-action" and "trans-action." The transactional framework:

... adopts as a reference entity the "whole" of the events-including the relation between the knower and the known-without identifying the eventual entities and the surrounding environment as $s u b$ stantiae, i.e., things that are ontologically separated and subsequently are found to have relationships (p. 9).

The transactional framework proposes, when applied to ecological and evolutionary phenomena, that the dichotomy between organism and environment should be overcome, with the idea of co-determination in the formation of an emergent new whole assuming primary importance. Some concepts or ideas in ecology and evolution can be adequately interpreted as instantiations of the transactional framework, such as Tansley's ecosystem concept, Odum's systemic ecology, Oyama's developmental systems theory, the idea of niche construction in evolutionary biology and ecology, or even, to take Earth as our object, Lovelock's ideas on the strong cybernetic integrations with co-determinations between living beings and physico-chemical environment, forming Gaia.

Of course, as Bergandi points out, this framework has also significant consequences not only for science, but also for moral philosophy. It offers good reasons for the extension of moral considerability to non-human animals, to non-human nature in general, since we, human beings, are seen as part of larger transactors, as part of societies, ecosystems or social-ecological systems, within which we, after all, acquire some meaning and have some duties.

Another idea that pervades the whole book, being examined by Bergandi and mentioned in other chapters, is the relationship between assertions of facts and assertions of values. In the proposal to integrate, on the one hand, science (in our case, ecology and evolution) and, on the other, ethics, it is crucial to face the problem of the relationship between these two kinds of assertions. The problem would be, as it became clearer with George Moore (1903/ 2000), based on his interpretation of David Hume's work, that we cannot simply deduce an ought-to-statement from an is-statement. Traditionally, the deduction of an ought-tostatement from an is-statement constitutes the naturalistic fallacy: the deduction of moral prescriptions from factual, scientific descriptions. The naturalistic fallacy would consist in a victory of science over ethics, a naturalization of ethical values and prescriptions (it happens, for instance, when somebody justifies some specific behavior he or she performs simply saying that it is natural). 
However, as Hilary Putnam (2002; see also Latour 1999, for arguments on overcoming this dichotomy) convincingly argued, we have no more reasons in post-positivist philosophy to accept such a rigidly established dichotomy between ought-to-statements and isstatements, between facts and values, between scientific claims and ethical claims. The work of Willard van Orman Quine (1951) and other post-positivist philosophers, such as Thomas Kuhn (1962), contributed, on the one hand, to show how science is not valueneutral, and how its factual statements about the natural world are socially or ethically laden. On the other hand, a serious analysis of ethical concepts (e.g., Putnam examines the case of cruelty) shows us that there is factuality (and then, objectivity) in our value judgments and they are not simply metaphorical or subjective ways to state what science could state in a more precise, objective, way, only talking about what would be the real facts.

But, as Putnam (2002) rightly qualifies, although facts and values are complexly interrelated in our judgments about us and about the world, this does not mean to assume a total lack of distinction. It is not necessary to also accept that there is no room for distinctions between statements about facts and statements about values, between a primarily scientific perspective, on the one hand, and a primarily ethical perspective, on the other hand.

The challenge for philosophy and other social practices (such as education), then, is to find the adequate middle term or the adequate qualified argument between the two wrong extreme positions: on the one hand, the strong modern and positivist dichotomy between facts and values (for which value judgments are not objective and part of the nonsensical, because they are neither analytic nor synthetic, in the positivist's jargon) and on the other hand, the assumption of a complete embeddedness of facts and values, as some postmodernist philosophers hold, not recognizing that there are, at least conceptually, differences to be drawn between facts and values (although they are ontologically embedded). In sum, there is a distinction to be drawn between objectivity in science and objectivity in ethics. Probably, a non-dichotomous distinction can be made, and this is of great importance in scientific educational practices today that seek to contextualize scientific content by ethical reflections or knowledge.

Particularly in an educational context, both the ideas of the transactional framework and the complex relationship between facts and values can be useful, at least, to show to students the convergences and the differences between ecology, evolution and ethics. And as such they seem important elements to be considered if we want to move toward a more integrated and really interdisciplinary curriculum in science or biology education (both in high school and in undergraduate or graduate levels).

\section{Evolution, Religion and Chance}

In the second chapter, entitled "Evolution Versus Creation: A Sibling Rivalry?" Michael Ruse advances a provocative and consistent argument: that evolutionists, since Thomas $\mathrm{H}$. Huxley and Herbert Spencer got the wrong way, when they thrived to turn evolutionary science into an ideology with its own morality. Doing this, they were putting evolutionary biology as a competitor to Christianity, which it should not be. This wrong way, Ruse argues, was continued in the twentieth century and survives today among other important evolutionary biologists, such as Edward O. Wilson (another good example here, although not mentioned by Ruse, would be Richard Dawkins). 
Ruse's argument - though short-is an interesting example of how philosophy of science can help scientists be more aware of the epistemological and ideological assumptions made in their own discourse, which has important implications for the very practice of science as well as for its teaching in schools or universities. In particular, for the biology teacher to be conscious of the issues raised by Ruse could be a significant advance in the way we conceive the relationships or conflicts between evolutionary and religious issues in the classroom.

In the third chapter, "Evolution and Chance," Jean Gayon examines the notion of chance in evolutionary studies. According to him, in order for the analysis of the role of chance in evolution to be meaningful, it is necessary to clarify: (1) what is understood by the word chance and (2) the scientific contexts in which the different notions of chance are used. From this point of view, he describes the three main meanings of chance in general, in order to clarify them:

(1) Luck, when something unexpected happens and it is not the consequence of a deliberate plan (p. 40). Here chance is understood in contrast to purposiveness (such as in "the gardener found a jewel, while digging in the terrain, in his pursuit of a different object")

(2) Random events, when "we have a hypothesis about what is random, and that we are able to show that we are indeed in a random situation" (pp. 40-41). Then, by definition a random event is one "that obeys a law of probability, freeing us of the notion of cause. An event that obeys a law of probability can be the result of a perfectly determinist causal process. This is the case in roulette or in dice games" (p. 41). The classic example is Quantum mechanics.

And, finally, (3) contingency with respect to a theoretical system, which Gayon explains through reference to classical mechanics. To understand chance as contingency in the context of a given theory is to say that the theory cannot predict events within its framework, because there is no sufficient available empirical or theoretical information or because there is no enough precision on the initial conditions, or, yet, because of the degree of complexity of the respective calculations.

Then, after this-let's call it, an a priori or syntactic — clarification, Gayon focuses on the uses of chance in the particular context of evolutionary studies, which, in turn, can be called an a posteriori or pragmatic analysis. Here he identifies five main uses of chance in evolutionary biology, which can be related to mutation, random genetic drift, genetic revolution, to the ecosystem level and finally to the macroevolutionary level. Gayon recognizes that there could be other cases (such as neutral and chaotic models), which would not fit into his scheme. And to finish, he poses two interlinked questions, which could be important for future research in history and philosophy of biology: "are the various modalities of chance that have been identified in evolutionist discourse truly distinct, or can they be reduced to a single concept?" (p. 46), and "... is this a subjective chance, that is, a chance that exists due to the limits of our knowledge, or an objective chance?" (p. 46).

\section{Organisms and Ecosystems, Physiology and Ecology}

In the fourth chapter, "Some Conceptions of Time in Ecology," Jean-Marc Drouin proposes that it is in the combination of characteristics of geology and physiology that ecology should be considered. Like geology - he proposes-ecology is a historical science, and like physiology, it is focused on processes. He proposes, however, that although initially 
grounded on the idea of a cycle, and after that, on the idea of organic growth, this trend changes because of the influence of the works of, among others, Alfred Lotka, Vito Volterra, Robert May, Ilya Prigogine and Isabelle Stengers. Because of this trend, the ecological processes started to be seen more from the perspective of unpredictability and chaos.

The analogy between ecology and physiology appears again in chapter seven, "Ecology and Moral Ontology," by J. B. Callicott. Callicott elaborates an interesting thesis on the old analogy between organisms and ecosystems. Traditionally, ecosystems have been considered as superorganisms, a thesis supported more or less strongly by different authors in Western thought, from Plato to Lovelock (Plato 1977; Clements 1916/2000; Lovelock 1988/1995).

According to Callicott, the reversal is more adequate: that organisms are superecosystems, an idea he elaborated from a suggestion made by ecologist Robert Ulanowicz. As Callicott warns us, in this reinterpretation of the analogy, "the prefix 'super' means superior in kind, not superior in size (bigger), nor superior in a conceptual hierarchy" (p. 107). The organisms are superecosystems in the sense that they magnify the properties we normally ascribe to ecosystems, such as being hierarchical, constituted by different subsystems, being self-regulating and being materially and energetically open. The reversal of the analogy can be very useful for ecological science and environmental ethics, and, perhaps, even the best way to save the analogy between organisms and ecosystems. A familiar example illustrates this very well, as Callicott points out: our own bodies are superecosystems in the sense required. In fact, our bodies are home to multitudes of bacteria or parasitic mites, occupying different habitats, interacting with different resources and conditions, just like the more traditional ecological biomes (the macroecosystems), such as deserts, forests or lakes (p. 108; see also the exciting human microbiome project; Proctor 2011).

Based on the reversal of this analogy, Callicott supports also an erotic ethic, according to him "the ethic of desire, the ethic of love-the postmodern erotic ethic" (p. 115). And he continues, "it stands in sharp contrast to the abstemious, zero-sum, self-sacrificial, guiltdriven - and ultimately ineffectual —ethic of the modern moral monadology" (p. 115). I agree with a general reference to love, although not with his interpretation of love as eros (love for what one does not have, strictly linked to desire; just think of how this is related to consumerism in the contemporary world), since it could alternatively be interpreted as agape (love as compassion, which is necessarily in favor of others). This, I think, would make a significant difference (see Comte-Sponville 2002). He approaches the threat of climate change and other global dangerous changes (p. 114). And according to him, "the modern moral monadology" is not efficacious as a solution to the threats of global climate change, for instance. But, in my opinion, Callicott's conclusion seems unsatisfactory against what he calls the "ethic of the modern moral monadology" (p. 115). For instance, Callicott does not offer a convincing argument when considering the mitigation of global climate change. To say that "one is called upon to curtail one's consumption so radically as to adopt a lifestyle that would make that of a cloistered Medieval monk seem voluptuous" (p. 114, emphasis added) is quite an exaggeration. It is possible to have a modest and at the same time very pleasant life, in accordance with some established social and environmental needs, but still very different from the life of a Medieval monk! The examples are abundant here.

Perhaps, here there is a problem in Callicott's ethical argument. Although I agree with the denial of the dichotomies (fact/value, subject/object, nature/society, etc.), just as mentioned above for the case of the fact/value dichotomy, which comes from modernity, 
from this denial does not follow that there is no room for distinctions. A distinction between assertions of fact and assertions of value would also be relevant, although there is no dichotomy between them. The radical proposal of completely dissolving or erasing the differences, because there is no dichotomy, leads us too far toward a relativistic, postmodern ethics. I do agree that we cannot anymore embrace Cartesian or positivistic ideas concerning this issue, but this does not mean that we need to go to the other, postmodern extreme position. And here, it seems to me that, instead of being the solution to the environmental problems, being less rigorous and less consistent in our actions, in our practices (as the postmodern erotic ethic seems to suggest), is precisely one of the sources of our problems in the environmental arena.

Although I disagree with part of Callicott's argument, mainly his ethical proposal, I think this should not obscure other arguments he advances, which seem better supported, mainly the one about organisms as superecosystems.

\section{Darwinism and the Naturalization of Values}

The fifth chapter, "Facts, Values, and Analogies: A Darwinian Approach to Environmental Choice," by Bryan Norton, is a provocative, controversial but interesting one. He proposes a pragmatic approach to allow a "re-examination of spatio-temporal scaling in the conceptualization of environmental problems and human responses to them" (p. 63).

I think that some issues are simply taken for granted by Norton and not discussed as deeply as they should be (probably, at least in part, this is due to the limited space in the book, which is understandable). Anyway, Norton supports some controversial ideas in his chapter, which deserve to be carefully considered.

First, in his defense of a naturalistic approach to values (in his words, "the method of experience"), Norton dismisses too easily the role of intuition or emotions in the environmental choices, in the analysis of previous arguments by Callicott (2002) and Sagoff (2004). According to Norton, the "non-natural qualities" appealed to by Callicott and Sagoff

are, apparently, apprehended through intuition or created by emotional affects and they seem illsuited to provide inter-subjectively valid or convincing reasons for environmental action. Worse, they tend to isolate discussions of environmental values from environmental science (p. 66)

In this passage, Norton underestimates the role of emotion and-as an extension-of virtues (see for instance, Comte-Sponville 2002) - in our choices about the environment, there seems to exist lots of reasons to consider intuitions, emotions or virtues as important elements in relation to values.

I agree with Norton that it is not good to isolate discussions of environmental values from environmental science (after all, there are some natural and social facts we need to know and science is an efficient and beautiful way to get closer to that). But, nevertheless, it seems an error to assume that intuitions, emotions, subjective feelings have no role to play in human decisions concerning the environment, and as a consequence, we should, then, support our decisions only on science. Here Norton assumes a perspective that seeks to naturalize values ("adaptive management 'naturalizes' the expression of values," p. 77), which can lead to a scientistic and technocratic perspective in environmental policy, even dangerous in educational practices which could not recognize the role that other knowledge (for instance, traditional ecological knowledge) could play in management. Curiously, though being so much attached to scientific knowledge and with a harsh critique of the 
appeal to non-natural qualities and emotions, by Callicott and Sagoff, Norton refers to respect and love for the land in his naturalistic approach to values. If, on the one hand, this could create a tension in his argument, I think, on the other, that this should be seen as reason to overcome the limitations of the Darwinian analogy, taking more altruistic values or virtues into account, as pointed out below.

Second, another controversial idea proposed by Norton is the application of the Darwinian approach to values. This could even resemble a defense of social Darwinism or the survival of the fittest in what concerns the interaction with ecological systems, not adequately considering, then, moral and political issues that could not simply be approached by a naturalistic, Darwinian perspective.

After providing his scheme for definitions of sustainability, Norton invites us to

consider the problem of choosing a sustainable environmental policy as a parallel adaptive game. As in evolution, winning in this game is for members of the group to stay alive to play another generation and the biggest winners are the ones who keep their markers in the game for the longest time (p. 79, emphasis added).

More specifically, Norton suggests the application of the genetic analogy of "evolutionary landscapes," proposed by Sewall Wright:

To apply Wright's analogy at the level of cultural survival, two important changes would be required. First, as conscious users of symbols, humans have foresight and, unlike other organisms, can, in principle at least, forgo the immediate rewards gained by ascending a steep slope to a low peak if they can see much greater benefits in seeking a higher peak. So our cultural application of Darwinism opens the possibility of balancing a choice between the steepness of slope (short term edge in competitiveness) and the height of the peak pursued (long-term survival options). Wright's fiction of an unchanging landscape in which organisms try to survive and adapt no longer holds. Adaptation, because of the introduction of consciousness, culture, and complex technologies, will be adaptation to a moving target, a dynamically changing environment in which traits that are adaptive today may become neutral or maladaptive in the future. (p. 80, emphasis added)

These ideas may sound intellectually interesting, but they could generate more problems than solutions, especially in the long run, which seem not to be adequately accounted for. The use of a Darwinian approach-with the mention of winners (in obvious contrast to losers) and competitiveness being symptomatic - creates a problem in this context: how to reach justice between the human groups concerning their interactions to the ecological systems, in a global level, with such an emphasis on competition?

Virtues such as solidarity, compassion-whose practice is made possible, at least in part, by intuitions, emotions and subjective feelings (which are made unimportant by Norton in these debates) - by another perspective can be seen extremely relevant and a way to overcome the natural human trend to merely compete and survive. I say this not to deny the relevance of Darwinian thought or of science as a whole for the understanding of ourselves and of the non-human nature, but in order to highlight that the approach proposed by Norton presents serious problems concerning social justice. For instance, we could ask: What about the moral considerability of (human and non-human) groups which, at least in the beginning of the "adaptive game," are not able to survive, not able to win the adaptive game (for instance, poor people), because they had no opportunities in the past (for historical reasons)? Might we overcome the environmental crisis by pointing to an adaptive Darwinian game based on competition (which means that there will be winners and losers)? Or, yet, isn't it a kind of othering process (that is, the process of generating others, of marking and naming those thought to be different from oneself, or from the idealistic "Us" which conforms our own community [Weis 1995; Grove and Zwi 2006]) implied in the idea of competition, which is also manifested in the different prejudices (racism, 
religious prejudices, sexism, speciesism), the very source of at least some of our problems in the social and environmental arena?

There are many examples of social justice problems, linked to our interaction with the ecological systems. One very illustrative example is the case of electronic wastes (ewastes) in the Agbogbloshie dumpsite in Accra, Ghana's capital. Huge amounts of e-waste are sent to Ghana from more developed, industrialized societies, and there it has caused important environmental problems as well as diseases in Ghanaian people, including children (Agyeman and Carmin 2011; Bisschop 2014).

These issues are especially important, mainly if we notice that the environmental problems are tightly linked to social justice issues (compare, for instance, the relationships between Human Development Index (HDI) and ecological footprints in the different countries around the world; WWF 2014).

Therefore, it seems clear that if we want to reach a better future for all, we have to seriously (morally) consider other cultures, other social groups as deserving and needing to overcome the environmental problems they face in their local historical and geographical contexts. This is to be compassionate, not competitive.

However, although not having made the issues on social justice explicit, I think Norton would agree that we need to extend moral considerability to other humans (as well as non-human nature), in a compassionate way. This would be possible, since he proposes to focus on our value models, which are inherited not only by our children, but also by those that get convinced to use them, independently of being genealogically related to us. This has an interesting consequence for education, which when trying to spread new value models concerning our relationship with nature, can contribute to promote human cultural evolution as well as the co-evolution between social and ecological systems, taking more seriously the ones that have strongest needs than us. For instance, value models in principle can (and in practice should) advance and spread the values of compassion and love toward those who need most in the world, be they human or non-human animals. Perhaps, this is a positive contribution to environmental policies that we can get from Norton's chapter.

\section{Individualistic and Holistic Approaches in Ethics}

In chapter six, "Towards EcoEvoEthics," Patrick Blandin proposes that, based on a shift in ecological thought from the idea of stability or equilibrium of ecosystems to a co-change paradigm, ecology meets evolution. And as a consequence, he proposes that the conservation target must shift from the stability of ecological systems to their adaptability, a similar idea to the one of adaptive management, by Norton (2005).

Based on this, Blandin proposes that we should go beyond the biocentrism versus anthropocentrism debate, toward a more integrated field, which he calls EcoEvoEthics.

It is not trivial to reach this conclusion, since the paradigm shift in ecology, from the idea of stability or equilibrium to the idea of a co-change (which converges substantially with the transaction framework, mentioned above) required the development of an ethics consistent with this new evolutionary, co-changing perspective in ecology. In this context, original ideas from Julian S. Huxley, in 1957, and latter contributions by Otto Frankel (1974) and Frankel and Michael Soulé (1981) were important. Particularly, Frankel and Soulé's idea of "evolutionary potential" was fundamental. According to Blandin: 
In this scientific context, the aim of nature conservation should be to preserve the biosphere's evolutionary potential, in order to maintain the sustainability of ecological processes, despite changes in the composition and organization of ecological systems. The biosphere's permanent adaptability becomes the target (p. 91).

This leads to a fundamental problem, posed by Frankel and Soulé, and examined by Blandin: do we want to preserve the biosphere because we value life for itself or because the continuation of ecological processes on Earth is necessary for the continuation of the existence of our own species? (p. 93). This leads to the complicated "substitution problem" (Birnbacher 2004), which is also carefully examined by Blandin. Whether the different living species should be preserved for unique reasons, which are related to themselves because what they do is specific to the relationships they establish with the environment, or whether they are replaceable, because what matters most is some less specific role that contributes to the maintenance of ecosystem services, is a hard question to answer. Now we can see that it is very hard to solve these problems, at least from the point of view of science only.

Based on his rich analysis, Blandin then paraphrases Leopold's Land Ethic (Leopold 1949), proposing that "a thing is right when it tends to enhance the biosphere capacity to evolve” (p. 97). In fact, we can see Blandin's work as proposing an extension of Leopold's thought (which was very much focused on the land as territory, not the land as Earth) to the scale of the planet as whole (since he has a focus on the biosphere). In sum, Blandin proposes a holistic approach to environmental ethics - in the line of Leopold's—based on contributions from integrated evolutionary biology and ecology.

In turn, in chapter eight, "Animal Rights and Environmental Ethics," Tom Regan exposes, very briefly, his argument in favor of the extension of rights to non-human animals, beginning with the defining characteristics of moral rights, in his words, no trespassing, equality, trump and respect. These are features he developed and explained better in older works, such as the well known The Case for Animal Rights (Regan 1994) and Empty Cages: Facing the challenge of animal rights (Regan 2003a). Then, he faces the issue of the extension of moral considerability, by asking: "who has moral rights?" (p. 119). And the answer is: the subjects-of-a-life. The idea of subjects-of-a-life illuminates our moral equality, according to Regan, since it points to those features that we humans have in common with other animals. Subjects-of-a-life are the animals that, among other features, experience the world, are able to feel and have a history of its own. Or as Regan (p. 120) puts it: "From the moral point of view, each of us is equal because each of us is equally a somebody, not a something, the subject-of-a-life, not a life without a subject." According to Regan, this set would include all mammals and birds, certainly, and all fishes, very probably.

The way Regan builds his argument is inspiring; he starts with human beings, showing that we have more than good reasons to accept equality concerning moral rights among human beings [according to Regan, we should locate the border of moral considerability for human beings "somewhere in the neighborhood of seven billion of us, regardless of where we live, how old we are, our race or gender or class, our religious or political beliefs, our level of intelligence..." (p. 120)]. And only after approaching how the idea of subjectsof-a-life applies to human beings, in a cumulative argument, he faces the problem of animal rights. This is inspiring because it shows that there is no contradiction, as some critics want to say, between moral considerability of human animals and non-human animals. Instead, the moral considerability of non-human animals can very consistently follow from the fact that we already morally consider human beings as subjects-of-a-life. 
In the context of this debate, an objection raised by Callicott (1989) misses completely the point of an animal ethics based on rights, when he says that "Regan's theory of animal rights implies a policy of human predator extermination, since predators, however innocently, violate the rights of their victims" (p. 122). This does not do any harm to Regan's rigorous philosophy. This critique is clearly inappropriate: among other reasons, it simply does not recognize that predators are not moral agents, which could possibly think about their actions of predation and, then, morally and rationally, decide what to do. And, moreover, in natural environments prey do not need to be protected against their predators (although they need to be protected in other ways, mainly from some human beings' actions, such as hunting). We, human animals, are moral agents and can rationally decide what to do. For instance, it is a question for us whether we should morally consider nonhuman animals (for more details on the objections against Regan's rights view and his answers, see Regan 2003b, p. 99).

Although consistent, Regan's theory faces an important limit, in some way similar to Peter Singer's (1975) utilitarian theory: it is focused on individuals (at least the ones which qualify as subjects-of-a-life). Thus, it cannot account (at least not as efficiently as it accounts for the moral considerability of individual animals) for entities that are not subjects-of-a-life. Although his theory offers-I think-good arguments for the moral considerability of non-human animals (including endangered or rare species or farm animals, for instance), which if followed would have revolutionary consequences (for instance, the elimination of the sport called "hunting" or food production based on exploitation of animal lives), it cannot account for-as he admits-the moral considerability of plants and insects.

To do so, I think, it would be necessary to assume a more ecologically oriented perspective, integrated with an individualistic one. For instance, we would have to think more about the reasons why plants and insects, for instance, are important in our ecological and social-ecological systems. Here we could find lots of reasons, one being that they are important conditions for the very protection of subjects-of-a-life. This is because some animals, which are subjects-of-a-life, depend on plants and on other animals (such as insects) to feed, to find shelter, to have a more adequate environment, which could establish the conditions for their persistence and integrity. In fact, it is an ecological truism that in ecosystems (as well as in social-ecological systems) all components, among them animals, plants and microorganisms, are interlinked through their ecological actions or roles, depending upon each other. Although Regan does not develop his argument in this line, it could possibly follow this way, but this certainly would demand a more serious consideration of ecological theories as well as a more holistic perspective in environmental ethics (perhaps recognizing that we have indirect duties toward plants and insects, for the reasons just sketched).

The topic of individualistic versus the holistic perspectives in environmental ethics is also approached in Robin Attfield's chapter, titled "Reconciling Individualist and Deeper Environmentalist Theories? An Exploration." He takes as a starting point a debate between himself and Alan Carter, concerning "whether an individualistic environmental ethic can be combined and reconciled with an ecocentric or holist ethic" (p. 127). Attfield builds his position against the value pluralism advocated by Carter (p. 131).

In this context, a significant example of the problem at stake is the trade-off between systems (e.g., ecosystems, communities, populations) on the one hand and individuals, on the other (in some way correlating to the ecocentric vs. individualistic ethics), when concerning moral considerability in the scientific practice of biologists and ecologists. Traditionally, evolutionary biologists and conservation ecologists (just to take two 
examples) tend to assume ecocentric values (although very often implicitly), which are linked to their emphasis on ecological or evolutionary wholes (such as populations, species, communities and ecosystems) at the expense of neglecting individualistic values (such as the fact that animals are subjects-of-a-life or sentient beings). This asymmetry of moral considerability can be observed in the very technical procedures used by these scientists in their data collection that, very often, does not adequately consider the individuals. Here it seems that if, on the one hand, evolutionary biologists and conservation ecologists tend, in general, to neglect the interests of individuals (a good example here is Aldo Leopold, who used to hunt!), on the other hand, individualists who support the rights view, such as Regan, do not adequately develop arguments toward a more holistic environmental ethic. Concerning this particular problem in the context of the biologist's decision-making, I think the more consistent starting point would be to assume the rights view, in the first place, thus extending moral considerability to all subjects-of-a-life, and then, only after that, assume indirect duties concerning living entities that are not subjectsof-a-life (plants and insects, for instance) and ecological wholes (communities and ecosystems, for instance), precisely because these entities are conditions of possibility for the preservation of rights of the subjects-of-a-life (in a dialectical, but not symmetrical relationship).

Attfield's chapter approaches a hard problem for ethics, especially because it has consequences for our decision-making in the social and environmental issues in the twenty-first century, particularly in the education of the new biologists. As an example, just think of how the dilemma between an individualistic and holistic ethic would reflect a development of new collection methods in the biological sciences as well as in the way we should educate the new biologists. Although Attfield advances good arguments against Carter's value pluralism, supporting instead a variation of biocentrism, the issue of monism versus pluralism in environmental ethics seems far from being resolved. And here, Attfield's chapter is a good reference to approach the debates between monists and pluralists, or between individualists and holists in environmental ethics.

\section{Historical and Ideological Roots of the Environmental Crisis}

In chapter ten, "Two Philosophies of the Environmental Crisis," Catherine Larrère calls the attention for a not well-noticed division in Environmentalism, which goes to relevant historical roots of the problem of our environmental crisis. According to her:

Because there are two ways of explaining the environmental crisis, there are two ways of addressing it, and two different ethics: an ethics of respect for nature (which we will call the "naturalistic environmental ethics") and an ethics of responsibility (which we will call the "ethics of technology"). (p. 143).

Each ethics ignores the other, creating a dichotomy, but Larrère proposes that they could be integrated. As a reason to overcome this old dichotomy between the two environmental ethics, Larrère cites the case of objects that are neither clearly natural nor artificial or technological, such as the genetically modified organisms (GMOs). GMOs are, on the one hand, produced by human technological procedures, and because of this, they can be said artificial. But, on the other hand, they live and reproduce by themselves, naturally, just as other natural living beings (another good example would be some nanomaterials, which do not exist in nature in some complex organizational structures, but only after a human intervention were made possible; for the issue of the natural and 
artificial imbrications as well as the environmental dangers of nanotechnology, see Schiemann 2005 and Preston 2005).

Although today it is clear that technological environmental ethics is much more hegemonic ideologically than the naturalistic environmental ethics, in a victory that has been lead more recently by the concept of sustainable development (see also Bergandi 2014), Larrère points to (but, unfortunately, does not develop the argument sufficiently to be convincing) a possible synthesis between these two environmental ethics, and between the notions of respect (from naturalistic environmental ethics) and responsibility (from technological environmental ethics).

First, in order to overcome the strong predominance of responsibility over respect, we would need also to acknowledge alterity, which means "not necessarily radical exteriority, but something which stands by itself, which has its own life, a self-sustaining process." (p. 148). Interestingly, there are similarities here with the idea of transactor (see above).

And, second, according to Larrère, we would have also to recognize that nature is the very object of the debate, in a way that an understanding, for instance, of what is natural (a metaphysical issue) would be an important part of the debate. As a consequence, it would be an unsatisfying solution to the environmental crisis simply to get rid of nature in environmental debates, as Bruno Latour (1999/2004) proposed.

Perhaps another possible common ground for both ethics-since they appeal to respect and responsibility - could be some kind of virtue ethics, but this is something that needs more careful examination.

Finally, the last chapter of the book, entitled "Epilogue: The Epistemic and Practical Circle in an Evolutionary, Ecologically Sustainable Society," is written by Bergandi. He concludes the book with a beautiful and deep analysis of the current social-environmental crisis; an analysis which, in spite of the huge challenges we face, can be seen as offering reasons for hope. Although reality may sound quite sad and deceptive, at least when it comes to our social and environmental problems, hope and optimism are necessary in this moment of history, to fuel and inspire more-both epistemically and morally_virtuous actions in the twenty-first century.

Bergandi sketches very clearly an image of the spectrum of social models we have to choose concerning our interactions with nature. In one extreme "there is a social model based on 'survival of the fittest,' where the struggle for existence between the members of a society, and with the members of other societies, continues to sustain a predatory relationship with the rest of nature" (p. 152). However:

at the other extreme is a more cooperative kind of society, where an enlarged common good is pursued-a common good that is not limited simply to certain short-term specific human interests, that clearly recognizes the right of other non-human species to an existence and that values the persistence of the environments that allow these species to survive and proliferate (p. 152)

Associated to these models of society, there is the emblematic and classical (but not outdated!) opposition between preservationism and conservationism, well examined by Bergandi. While preservationism is more focused on "nature and its equilibrium, and more particularly, the wilderness, a state of nature where evolutionary processes can come into existence without encountering any major hindrances from human activity" (p. 152), conservationism, in turn, is a more anthropocentric perspective, giving special consideration to "human society and its economic order, which, in the best scenarios, will make 'wise use' of natural resources" (p. 153).

Bergandi reminds us the ideological commitments, and their consequences, when we simply accept that we should support a conservationist perspective (as it is more and more 
common in ecological science, for instance), since "such a conservationist perspective on the man-nature relationship underlies the sustainable development paradigm, which tends to be assumed as a guiding principle by governments, international institutions, corporate business, civil stakeholders and the public.” (p. 153). The serious internal (logical, but also practical) contradictions in the ideology of sustainable development will probably, as Bergandi notices, undermine it, determining "its fiasco" (p. 154). For a more recent analysis of the topic, see Bergandi (2014).

Another interesting topic in Bergandi's epilogue, although not explicitly mentioned by him, is linked to education and deserves our attention. According to Bergandi, the socioscientific controversies are characterized by "complex linkages between some life and environmental sciences objects and economic, political and ethical issues" (p. 151). In this context, according to him, "a posture of transparent, impartial commitment is appearing, more and more, as a deontological necessity." (p. 151). Interestingly, the socio-scientific controversies have an educational counterpart on a strategy to teach science, in different educational levels (from high school to graduate studies) in a more critical and contextualized manner, the Socio-Scientific Issues (SSI). The SSI are teaching strategies based on controversial problems which, for their solutions, require scientific knowledge, but also other kinds of knowledge as well as ethical values (Zeidler et al. 2005). Although the SSI, as any educational tool, can be misused (see, for instance, Solli et al. 2014), they tend to contribute to the development of critical thinking and autonomy of students who engage in learning science as well as other disciplines in this way.

\section{Closing Remarks}

This book is a very well organized one, covering various scientific and philosophical issues and debates. It is a highly recommended reading for a wide audience, including ecologists, evolutionary biologists and philosophers interested in environmental issues. In the classroom, with some effort made by teachers, it could be used in high school biology classes, although, in my opinion, it is much more appropriate for undergraduate and graduate courses. Particularly in these cases, it can also be useful in introductory courses in environmental ethics as well as in history and philosophy of ecology/evolution courses. The fact that the chapters are independent from each other allows for different selections of them to compose the bibliography of a course.

More specifically, a way to use this book in the classroom could be through the design and application of SSI, grounded on the theoretical frameworks or cases expounded in the book. Perhaps, a science education which takes ethics and politics more seriously into account, through SSI, for instance, aiming at teaching and providing ways to the practice of social-political actions (sensu Hodson 2004) by the students, could play a decisive role in the transformation of the current value systems which guide our interactions with nature and among ourselves (Freire 2004; Kahn 2010). Significantly, in this context of a SSIbased scientific education aiming at social-political actions, science education cannot focus anymore on conceptual content only (that is, definitions, facts and theoretical principles of science). Instead, educational practices in science (and here the education of new scientists, in undergraduate and graduate levels, is completely included!) should also, explicitly and critically, address values and actions in their teaching strategies (after all, values and actions are also educational contents; see Coll et al. 1992; Zabala 1998; Clément 2006). It would also be consistent if these strategies could try to reach values and 
actions mainly from the point of view of moral philosophy and environmental ethics; values and actions which should not only be intellectually and critically understood as concepts, but embraced and practiced in the social and political arena.

Hopefully, for all its virtues, this book may contribute in the future to such a transformation toward a more integral and critical education, mainly if used in the education of new biologists in undergraduate and graduate courses.

\section{References}

Agyeman, J., \& Carmin, J. (2011). Introduction: Environmental injustice beyond borders. In J. Carmin \& J. Agyeman (Eds.), Environmental inequalities beyond borders: Local perspectives on global injustices (pp. 1-15). Cambridge, MA: MIT Press.

Bergandi, D. (2014). Environnement, éthique et politique: les limites d'une démocratie inaboutie et leurs conséquences néfastes sur la protection de la nature. Éthique publique [En ligne],. doi:10.4000/ ethiquepublique. 1364.

Birnbacher, D. (2004). Limits to sustainability in nature conservation. In M. Oksanen \& J. Pietarinen (Eds.), Philosophy and biodiversity (pp. 180-195). Cambridge, MA: Cambridge University Press.

Bisschop, L. (2014). How e-waste challenges environmental governance. International Journal for Crime, Justice and Social Democracy, 3(2), 81-95.

Callicott, J. B. (1989). In defense of the land ethic: Essays in environmental philosophy. Albany: State University of New York Press.

Callicott, J. B. (2002). The pragmatic power and promise of theoretical environmental ethics. Environmental Values, 11, 3-25.

Clément, P. (2006). Didactic transposition and KVP model: Conceptions as interactions between scientific knowledge, values and social practices. In ESERA Summer School (pp. 9-18). Braga: University of Minho.

Clements, F. E. (1916/2000). Plant succession: An analysis of the development of vegetation. In D. R. Keller \& F. B. Golley (Eds.), The philosophy of ecology: from science to synthesis (pp. 35-41). Athens, London: University of Georgia Press.

Coll, C., Pozo, J. I., Sarabia, B., \& Valls, E. (1992). Los contenidos en la reforma: enseñanza y aprendizaje de conceptos, procedimientos y actitudes. Buenos Aires: Ediciones Santillana S.A.

Comte-Sponville, A. (2002). A small treatise on the great virtues: The uses of philosophy in everyday life. New York: Metropolitan Books.

Dewey, J. (1930/1984) Conduct and experience. In C. Murchison (Eds.), Psychologies of 1930 (pp. 409-422), Worcester: Clark University Press. Repr. Boydston, J. A. (Eds.) The later works of John Dewey 1925-1953, v. 5, 1929-1930 (pp. 218-235), Carbondale and Edwardsville: Southern Illinois University Press.

Dewey, J. \& Bentley, A. F. (1949/1989) Knowing and the known. Boston: The Beacon Press. Repr. Boydston, J. A. (ed.) The later works of John Dewey 1925-1953, v. 16, 1949-1952 (pp. 1-294). Carbondale and Edwardsville: Southern Illinois University Press.

Frankel, O. H. (1974). Genetic conservation: Our evolutionary responsibility. Genetics, 78, 53-65.

Frankel, O. H., \& Soulé, M. E. (1981). Conservation and evolution. Cambridge/New York: Cambridge University Press.

Freire, P. (2004). Pedagogy of indignation. Boulder CO: Paradigm Publishers.

Grove, N. J., \& Zwi, A. B. (2006). Our health and theirs: Forced migration, othering, and public health. Social Science and Medicine, 62, 1931-1942.

Hodson, D. (2004). Going beyond STS: Towards a curriculum for sociopolitical action. Science Education Review, 3(1), 2-7.

Kahn, R. (2010). Critical pedagogy, ecoliteracy, and planetary crisis: The ecopedagogy movement. New York: Peter Lang.

Kuhn, T. (1962). The structure of scientific revolutions. Chicago: University of Chicago Press.

Latour, B. (1999). Politiques de la nature: comment faire entrer les sciences en démocratie. Paris: Editions La Decouverte.

Leopold, A. (1949). A sand county almanac and sketches here and there. Oxford: Oxford University Press. Lovelock, J. E. (1988/1995). The ages of Gaia: a biography of our living earth. New York: W.W. Norton \& Company. 
Moore, G. E. (1903/2000) Principia Ethica. (2nd ed.). Cambridge, UK/New York: Cambridge University Press.

Norton, B. G. (2005). Sustainability: A philosophy of adaptive ecosystem management. Chicago: University of Chicago Press.

Plato. (1977). Timeu. Trad. Carlos Alberto Nunes. Belém: Universidade Federal do Pará.

Preston, C. J. (2005). The promise and threat of nanotechnology. Can environmental ethics guide us? HYLE-International Journal for Philosophy of Chemistry, 11(1), 19-44.

Proctor, L. M. (2011). The human microbiome project in 2011 and beyond. Cell Host and Microbe, 10, 287-291.

Putnam, H. (2002). The collapse of the fact/value dichotomy and other essays. Cambridge MA/London: Harvard University Press.

Quine, W. V. O. (1951). Two dogmas of empiricism. The Philosophical Review, 60, 20-43. Repr Quine, W. V. O. (1953) From a Logical Point of View. Cambridge, MA: Harvard University Press.

Regan, T. (1994). The case for animal rights: A decade's passing. In R. T. Hull (Ed.), A quarter century of value inquiry: Presidential addresses of the American Society for Value Inquiry (pp. 439-459). Amsterdam/Atlanta, GA: Editions Rodopi.

Regan, T. (2003a). Empty cages: Facing the challenge of animal rights. Oxford: Rowman \& Littlefield Publishers.

Regan, T. (2003b). Animal rights, human wrongs: An introduction to moral philosophy. Oxford: Rowman \& Littlefield Publishers.

Sagoff, M. (2004). Price, principle, and the environment. Cambridge/New York: Cambridge University Press.

Schiemann, G. (2005). Nanotechnology and nature. On two criteria for understanding their relationship. HYLE-International Journal for Philosophy of Chemistry, 11(1), 77-95.

Singer, P. (1975). Animal liberation. New York: Avon Books.

Solli, A., Bach, F., \& Akerman, B. (2014). Learning to argue as a biotechnologist: Disprivileging opposition to genetically modified food. Cultural Studies of Science Education, 9, 1-23.

Weis, L. (1995). Identity formation and the process of "othering'": Unravelling sexual threads. Educational Foundations, 9(1), 17-33.

WWF. (2014). Living planet report 2014: Species and spaces, people and places. Gland, VD, Switzerland: World Wide Fund for Nature.

Zabala, A. (1998). A prática educativa: como ensinar. Porto Alegre: Artmed.

Zeidler, D. L., Sadler, T. D., Simmons, M. L., \& Howes, E. V. (2005). Beyond STS: A research-based framework for socioscientific issues education. Science Education, 89, 357-377. 